\title{
Hubungan Pendidikan Kesehatan dengan Kejadian Hiperbilirubinemia di Rumah Sakit.
}

\author{
Deswita $^{\mathrm{a}}$ \\ ${ }^{a}$ Fakultas Keperawatan Universitas Andalas \\ Email : deswitapsik@yahoo.com
}

\begin{abstract}
The purpose of the research was describe the effect of health education at knowledge and attitude of the mother, and insidence of hyperbilirubinemia at the newborn. The research was quasi experimental with pretest posttest design. The samples were 30 post partum and devided into two group, control and intervention group. Samples selected with non probability sampling-concecutive sampling. The result showed that post partum knowledge and attitude was increased after intervention. Incidence of hyperbilirubinemia in intervention group is higher than control group $(p=0,651)$. The research recomended that health education should be given since antenatal periode.
\end{abstract}

Key words: health education, mother, hyperbilirubinemia.

\begin{abstract}
Abstrak: Tujuan penelitian ini adalah untuk mendapatkan gambaran hubungan pendidikan kesehatan terhadap kejadian hiperbilirubinemia pada bayi baru lahir. Penelitian ini menggunakan metode dekriptif analitik. Sampel penelitian adalah ibu yang berkunjung ke Poliklinik Anak RSUP Dr.M.Djamil Padang, sebanyak 30 orang. Teknik pengambilan sampel dilakukan secara non probability sampling dengan jenis purposive sampling. Hasil penelitian menunjukkan bahwa tidak ada hubungan antara pendidikan kesehatan dengan kejadian hiperbilirubin. Penelitian ini merekomendasikan bahwa pendidikan kesehatan hendaknya diberikan pada ibu mulai dari saat antenatal.
\end{abstract}

Kata Kunci : pendidikan kesehatan,ibu, hiperbilirubinemia

Hiperbilirubinemia adalah akumulasi bilirubin dalam darah yang berlebihan, ditandai dengan adanya jaundice atau ikterus, perubahan warna kekuningan pada kulit, sklera dan kuku (Hockenberry \& Wilson, 2009). Hiperbilirubinemia pada neonatus dapat muncul dalam salah satu dari dua bentuk berikut ini: hiperbilirubinemia tidak terkonyugasi / indirek atau terkonyugasi/direk. Tanda yang paling mudah dilihat atau diidentifikasi dari kedua bentuk tersebut adalah "kulit dan selaput lendir menjadi kuning”. Hiperbilirubinemia pada neonatus dapat terlihat nyata jika bilirubin kadar bilirubin dalam darah lebih dari atau sama dengan $5 \mathrm{mg} / \mathrm{dl}$ (Indrasanto et al, 2008). Hiperbilirubinemia yang terjadi pada bayi baru lahir umumnya adalah fisiologis, kecuali: timbul dalam 24 jam pertama kehidupan, bilirubin indirek untuk bayi cukup bulan $\geq 13 \mathrm{mg} / \mathrm{dL}$ atau bayi kurang bulan $\geq 10 \mathrm{mg} / \mathrm{dL}$, peningkatan bilirubin $>5 \mathrm{mg} / \mathrm{dL} / 24$ jam, kadar bilirubin direk > $2 \mathrm{mg} / \mathrm{dL}$, hiperbilirubinemia menetap pada umur $>2$ minggu dan terdapat faktor risiko (Moeslichan, 2004).

Hiperbilirubinemia pada bayi baru lahir dapat terjadi selama bayi masih dirawat di rumah sakit dan beberapa hari setelah bayi pulang dari rumah sakit. Pemulangan dini pada bayi baru lahir dari rumah sakit berhubungan dengan peningkatan dirawatnya kembali bayi dengan hiperbilirubinemia (Peterson et al, 2005).

Perawat anak yang profesional mempunyai tanggung jawab untuk memberikan layanan berkualitas tinggi. Salah satu peran paling penting perawat anak adalah pendidik. Pendidikan kesehatan yang lebih populer dengan istilah penyuluhan bagi pasien di 
lingkup rumah sakit diberikan oleh perawat di ruang perawatan dan di rawat jalan. Pendidikan kesehatan yang diberikan oleh perawat diharapkan dapat mengubah pengetahuan, sikap dan keterampilan ibu post partum dalam memberikan perawatan pada bayi baru lahir, terutama untuk

\section{METODE}

Penelitian ini merupakan penelitian deskriptif analitik dengan pendekatan cross sectional. Penelitian ini bertujuan untuk mengetahui apakah ada hubungan pendidikan kesehatan dengan kejadian hiperbilirubin pada neonatus. Pendidikan kesehatan tentang pencegahan bilirubin diberikan kepada ibu selama di rumah sakit sementara kelompok control tidak diberikan pendidikan kesehatan. Pendidikan kesehatan diberikan pada ibu sesuai dengan modul pendidikan kesehatan

\section{HASIL DAN PEMBAHASAN}

Hubungan pendidikan kesehatan dengan kejadian bilirubin.

\section{Tabel 1. Hasil Uji Statistik}

\begin{tabular}{|c|c|c|c|c|c|}
\hline $\begin{array}{c}\text { Kelomp } \\
\text { ok }\end{array}$ & \multicolumn{2}{|c|}{$\begin{array}{c}\text { Hiperbili- } \\
\text { rubin }\end{array}$} & \multicolumn{2}{|c|}{$\begin{array}{c}\text { Tidak } \\
\text { Hiperbili } \\
\text { rubin }\end{array}$} & Sig. \\
\cline { 2 - 5 } & $\mathrm{N}$ & $\%$ & $\mathrm{~N}$ & $\%$ & 0,25 \\
\hline $\begin{array}{c}\text { Interve } \\
\text { nsi }\end{array}$ & 4 & $\begin{array}{c}26,7 \\
\%\end{array}$ & 1 & $\begin{array}{c}74,3 \\
6\end{array}$ & 6 \\
\hline Kontrol & 6 & $40 \%$ & 9 & $60 \%$ & \\
\hline
\end{tabular}

Hasil uji statistik menunjukkan tidak ada hubungan yang signifikan antara pendidikan kesehatan dengan kejadian hiperbilirubinemia $\quad(p=0,256 ; p<0,05)$. Artinya pendidikan kesehatan tentang pencegahan hiperbilirubin pada neonatus ternyata tidak berhubungan dengan kejadian hiperbilirubin pada neonatus yang datang berkunjung ke Poli Anak RSUP. Dr. M. Djamil Padang.

Penelitian ini tidak sesuai dengan pendapat Rodriguez, et al (2006) yang membahas 5 komponen strategi untuk penanganan hiperbilirubinemia dan pencegahan mengurangi angka kejadian hiperbilirubinemia.

Penelitian ini bertujuan untuk menguji apakah pelatihan kesehatan berpengaruh terhadap kejadian hiperbilirubin pada neonatus.

tentang pencegahan bilirubin pada neonatus di rumah. Kejadian hiperbilirubin diukur dengan melihat gejala klinis yaitu kulit dan selaput lendir menjadi kuning. Gejala ini akan diukur 7 hari setelah ibu dipulangkan dari rumah sakit. Sampel berjumlah $30 \mathrm{ibu}$ post partum yang terbagi atas 15 orang pada kelompok intervensi dan 15 orang pada kelompok control. Analisis data yang digunakan dalam penelitian ini adalah ChiSquare secara komputerisasi.

kernikterus yaitu penapisan umum hiperbilirubinemia, pendidikan untuk keluarga dan tim kesehatan, pendidikan laktasi untuk keluarga dan tim kesehatan, perangkat untuk mengkaji dan penanganan hiperbilirubinemia dan follow-up dini bayi baru lahir setelah pulang dari rumah sakit. Menurut peneliti hal ini disebabkan oleh karena pendidikan kesehatan harusnya diberikan pada masa prenatal pengulangan informasi yang diberikan postnatal dapt memperkuat informasi sebelumnya. Banyak informasi yang tidak dapat disebutkan kembali oleh ibu ketika ditanyakan kembali saat ibu konsul ulang ke Poli Anak RSUP. Dr. M. Djamil Padang. Contohnya jawaban dari responden yang menyatakan bayinya banyak tidur dan meneteknya kurang. Kondisi ini mengakibatkan ketidakefektifan menyusui, sehingga berisiko meningkatkan kejadian Hiperberbilirubin. Kondisi ini telah pernah diinformasikan kepada ibu namun ibu ternyata tidak dapat menyebutkan apa yang harus dilakukan. Dalam pendidikan kesehatan Menurut Palmer, et al. (2003) dalam Rodriguez, Backus, Watson, Mannel dan Frye (2006) tidak efektifnya menetek pada bayi dalam kehidupan satu minggu pertama berisiko terjadinya reabsorpsi 
bilirubin dalam usus dan keterbatasan bayi baru lahir mengeluarkan bilirubin dalam urin dan feses.

Hal lainnya adalah banyaknya factor risiko yang ikut mempengaruhi hiperbilirubin pada neonatus. Faktor risiko tersebut antara lain ketidaksesuaian golongan darah ibu dengan bayi, prematuritas, sefalhematom, memar, trauma lahir dan keterlambatan pengeluaran mekonium (Porter \& Dennis, 2002; Hockenberry \& Wilson, 2007).

\section{KESIMPULAN DAN SARAN}

Hasil penelitian hubungan pendidikan ibu dengan kejadian hiperbilirubinemia pada bayi baru lahir tidak menunjukkan adanya hubungan dengan nilai $p=0,256$. Ada beberapa faktor menjadi penyebab hiperbilirubinemia seperti adanya ketidak sesuaian golongan darah ibu dengan bayi, prematuritas, sefalhematom, memar, trauma lahir dan keterlambatan pengeluaran mekonium (Porter \& Dennis, 2002; Hockenberry \& Wilson, 2007).

\section{Saran}

1. Bagi pelayanan keperawatan

a. Pendidikan kesehatan hendaknya diberikan mulai dari poliklinik kebidanan mencakup pemantauan terhadap kecukupan minum bayi serta pemberian ASI dan dampaknya terhadap kesehatan.

Hockenberry \& Wilson, M. J., \& Wilson, D. (2009). Essentials of pediatric nursing. Eight edition. St Louis: Mosby Elsevier

Hodikoh, A. (2003). Efektivitas edukasi postnatal dengan metode ceramah dan media booklet terhadap pengetahuan, sikap dan perilaku ibu tentang ASI dan menyusui dalam konteks keperawatan maternitas di kota Bogor dan Depok. Tesis: Tidak dipublikasikan

Imelda. (2009). Efektifitas pendidikan kesehatan terhadap pengetahuan dan b. Pendidikan kesehatan yang sudah dilakukan di ruangan dilanjutkan dan diberikan secara bertahap sesuai dengan kebutuhan ibu dan keluarga untuk dapat melakukan perawatan bayi di rumah.

2. Bagi ilmu Keperawatan

a. Perlu menanamkan kepada mahasiswa bahwa pendidikan kesehatan merupakan peran perawat yang sangat penting untuk meningkatkan kesehatan ibu dan bayi.

b. Institusi pendidikan juga perlu menggali berbagai strategi pendidikan kesehatan berdasarkan teori pembelajaran, sehingga peserta didik menjadi lebih kreatif dan efektif dalam memberikan pendidikan kesehatan.

3. Bagi penelitian berikutnya

Perlu dilakukan penelitian lanjutan dengan sampel yang lebih banyak dan dengan menganalisis faktor-faktor perancu terhadap kejadian hiperbilirubinemia pada bayi baru lahir diantaranya adalah dehidrasi dan efektifitas ibu menyusui bayi dan untuk variabel sikap dan keterampilan hendaknya dilakukan evaluasi dengan melakukan kunjungan rumah.

\section{DAFTAR PUSTAKA}

sikap ibu dalam stimulasi perkembangan anak todler di RSU Zainoel Abidin Banda Aceh. Tesis: Tidak dipublikasikan

Indrasanto, E., Dharmasetiawani, N., Rohsiswatmo, R \& Kaban, R.K. (2008). Paket pelatihan pelayanan obstetri dan neonatal emergensi komprehensif (PONEK): Asuhan neonatal esensial. Jakarta: JNPK-KR

Maulana, H. D. J. (2009). Promosi kesehatan. Jakarta: E.G.C 
Merenstein, G. B, \& Gardner, S. L. (2002). Hand book of neonatal intensive care. Fifth edition. St. Louis: Mosby

Moeslichan. (2004). Tatalaksana hiperbilirubinemia neonatorum. http://www.yan medik-depkes. net/hta/Hasil\%20Kajian\%20HTA/2004/ Tatalaksana\%20Hiper bilirubinemia\%20Neonatorum.doc diunduh tanggal 12 Januari 2010

Supartini, Y. (2004). Buku ajar konsep dasar keperawatan anak. Jakarta: EGC.

Yani, E. R. (2009). Pengaruh paket pendidikan kesehatan "Rindu" terhadap kesiapan ibu merawat bayi prematur setelah pulang dari rumah sakit di Kediri. Tesis: Tidak dipublikasikan

Yurika, D. (2009). Efektifitas pendidikan kesehatan terhadap pengetahuan, sikap dan keterampilan ibu dalam pemantauan perkembangan balita di kelurahan Sukaramai kecamatan Baiturrahman Banda Aceh. Tesis: Tidak dipublikasik 
